\title{
A Macroneuropteris scheuchzeri tree preserved in growth position in the Middle Pennsylvanian Sydney Mines Formation, Nova Scotia, Canada
}

\author{
Howard J. Falcon-Lang \\ Department of Earth Sciences, Royal Holloway, University of London, \\ Egham, Surrey TW20 0EX, UK. <h.falcon-lang@es.rhul.ac.uk>
}

Date received: 24 January 2009 Date accepted: 19 March 2009

\begin{abstract}
Fossil plants preserved in growth position provide important insights into the architecture and ecology of ancient plants. Here I describe an upright tree of Macroneuropteris scheuchzeri rooted above the Point Aconi Coal in the Middle Pennsylvanian Sydney Mines Formation of Nova Scotia - the first example of an autochthonous pteridosperm described in the literature. The fossil tree has a sharply tapering trunk surrounded in its lower part by a large number of downward-recurved senescent petioles, which form a skirt. Petioles borne in an upright or horizontal position, interpreted as fronds that were still photosynthetically active when buried, are confined to the uppermost preserved part of the tree. Adapted to growth in rapidly aggrading coastal wetlands, the skirt of Macroneuropteris scheuchzeri probably acted to prop up the trunk while additionally trapping large mounds of mud around the base of the tree and stabilizing coastal wetlands. The tree had a sprawling habit and a maximum height of about $2 \mathrm{~m}$. Similar, but smaller, trees found in adjacent beds probably represent juvenile specimens of the same species.
\end{abstract}

\section{RÉSUMÉ}

Les végétaux fossiles conservés dans leur position de croissance fournissent des renseignements précieux sur l'architecture et l'écologie des plantes anciennes. Je décris dans le présent document un Macroneuropteris scheuchzeri droit enraciné au-dessus de charbon de Point Aconi dans la Formation du Pennsylvanien moyen de Sydney Mines, en Nouvelle-Écosse - premier exemple de ptéridosperme autochtone décrit dans les ouvrages. L'arbre fossile possède un tronc nettement effilé entouré dans sa partie inférieure d'un grand nombre de pétioles sénescents recourbés vers le bas, qui forment une jupe. Des pétioles en position verticale ou horizontale, interprétés comme des frondes qui étaient encore actives sur le plan photosynthétique au moment de l'enfouissement, sont confinés à la partie la plus élevée de l'arbre conservée. Adaptée à la croissance dans les milieux humides côtiers d'alluvionnement rapide, la jupe du Macroneuropteris scheuchzeri servait probablement à maintenir le tronc et permettait en même temps d'emprisonner de gros monticules de boue autour de la base de l'arbre et de stabiliser les milieux humides côtiers. L'arbre, qui avait tendance à s'étendre, atteignait une hauteur maximale d'environ deux mètres. Des arbres semblables mais plus petits découverts dans des couches adjacentes représentent probablement de jeunes spécimens de la même espèce.

[Traduit par la redaction]

\section{INTRODUCTION}

Pteridosperms, or seed-ferns, were one of the most diverse and widespread elements of Late Paleozoic tropical rainforests (DiMichele et al. 2006). Although over a hundred years have passed since the first discovery of the group (Falcon-Lang 2008), remarkably few species are known as whole plants. Early attempts to reconstruct tree habit were mostly based on fragmentary material (Stewart and Delevoryas 1956) and subsequently widely reproduced in paleobotany textbooks. Trees were mostly reconstructed as shrubs $1-8 \mathrm{~m}$ high, with mono- axial trunks and leaves held in a horizontal or upright position (Pfefferkorn et al. 1984).

One of the dangers of such textbook reconstructions is that they ultimately become stereotypes that obscure the fact that each species had its own unique architecture. In an important paper, Wnuk and Pfefferkorn (1984) described parautochthonous assemblages of medullosan pteridosperms from Pennsylvania, USA. They proposed a number of wholeplant reconstructions that, being based on large trunk and petiole specimens, represented more secure interpretations than those previously proposed from fragmentary remains. 
Further, Wnuk and Pfefferkorn (1984) demonstrated, to a limited degree, the diversity of tree habits present within the group. Even so, their material was horizontal to bedding, representing the remains of fallen trees rather than upright plants. Consequently, little data could be obtained about the habit of the tree in life.

The purpose of this paper is to describe the architecture and habit of the medullosan pteridosperm Macroneuropteris scheuchzeri based on a specimen preserved upright in growth position, the first described example of its kind. Plant remains belonging to this morphospecies have an important place in the history of paleobotany. They were amongst the first fossil plants to be formally described using a pre-Linnean binomial system, appearing in Lhwyd (1699) under the name Phyllites mineralis and illustrated in the Herbarium Diluvianum (Scheuchzer 1709, 1723). At a later date, Hoffman (in Keferstein 1826) transferred these fossils to Neuropteris scheuchzeri before Cleal et al. (1990) placed them in the new morphogenus Macroneuropteris.

The frond architecture of Macroneuropteris macrophylla (Cleal et al. 1996, 1998) is generally better known than for Macroneuropteris scheuchzeri (Zodrow 2003) but recent observations have improved this situation (Laveine and Behlis 2007). Like Macroneuropteris macrophylla, Macroneuropteris scheuchzeri comprises a petiole more than one metre in length, which dichotomises near the base to produce two large bipinnate segments (Fig. 1; Beeler 1983; Cleal et al. 1996; Zodrow 2003; Laveine and Behlis 2007). However, the most striking characteristic of this morphospecies is its exceptionally large pinnules ( $>2 \mathrm{~cm}$ long, locally $\leq 12 \mathrm{~cm}$ long), which show thick cuticle, sunken stomata and dense arrays of adaxial trichomes (Schabilion and Reihman 1985; Zodrow 2003). Comparatively poorly known is the mode of attachment of these large petioles to the trunk, as well as the overall habit of the tree. The upright fossil tree of Macroneuropteris scheuchzeri buried in growth position and described herein helps fill this gap in our knowledge.

\section{GEOLOGICAL SETTING}

The fossil tree was found in sea cliffs at Point Aconi, near Sydney Mines, Cape Breton, Nova Scotia, Canada $\left(46^{\circ} 30^{\prime} \mathrm{N}\right.$; $60^{\circ} 17^{\prime} \mathrm{W}$; Fig. 1). Rocks at this site are part of the Pennsylvanian Sydney Mines Formation, which is divided in 14 depositional sequences or cyclothems (Gibling et al. 2004). Palynological and megafloral assemblages indicate that this formation is of Asturian-Cantabrian age, with the substage boundary occurring within Cyclothem 12, about $25 \mathrm{~m}$ above the Hub Coal Seam (Zodrow and Cleal 1985; Zodrow 1989a, b; Dolby 1988; Cleal et al. 2003). The fossil tree described in this paper occurs $1.6 \mathrm{~m}$ above the Point Aconi Coal Seam in Cyclothem 14 and therefore lies some $120 \mathrm{~m}$ above the Asturian-Cantabrian boundary (Fig. 2). These strata are probably time-equivalent with the uppermost Middle Pennsylvanian strata in the USA (Wagner and Lyons 1997).

The sedimentary succession of the middle portion of Cyclothem 14 is illustrated in Figure 3 (after Falcon-Lang 2006). The $5 \mathrm{~m}$ thick succession below the Point Aconi Coal represents the deposits of a retrograding coastal plain subject to brackish water influence, whereas the 1.1-m-thick coal was formed in a long-lived coastal mire forest (Gibling and Wightman 1994). Of special interest here is the 3.1-m-thick succession that overlies the Point Aconi Coal and contains upright fossil trees (Fig. 3). These strata comprise beds of medium- to dark-grey laminated shale bearing roots, with intermittent $1 \mathrm{~cm}$ thick layers of coaly shale. These beds are the deposits of shallow/emergent coastal wetlands that developed after coal formation (Falcon-Lang 2006). There is no evidence

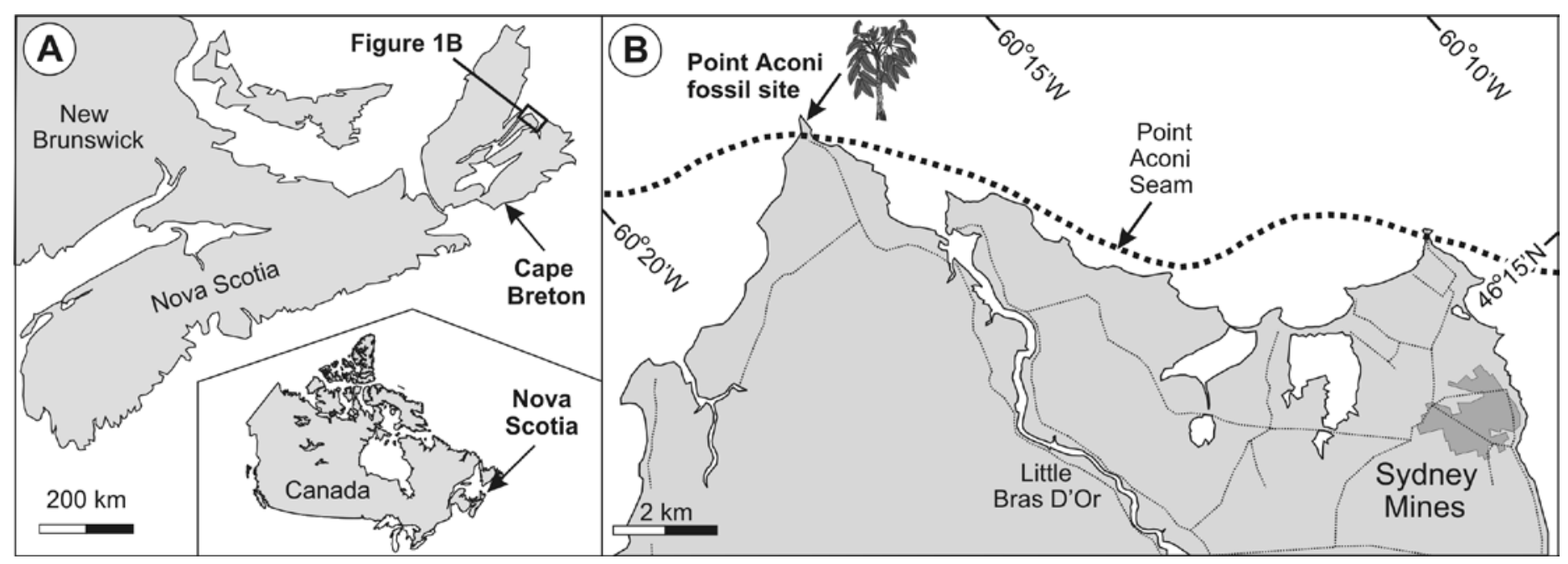

Fig. 1. Location details of fossil site. (A) Nova Scotia, inset: Canada. (B) Point Aconi, near Sydney Mines, Cape Breton. Fossil site marked with tree icon. 

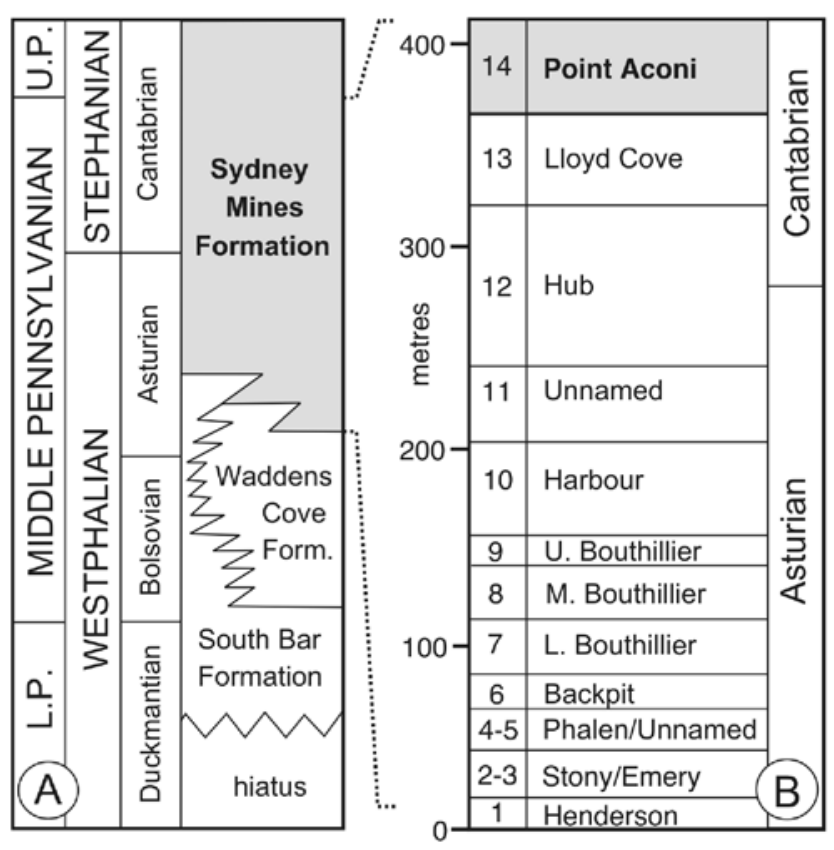

Fig. 2. (left) (A) Pennsylvanian stratigraphy of the Sydney Basin, Cape Breton. Abbreviations: L.P., Lower Pennsylvanian, U.P., Upper Pennsylvanian. (B) Stratigraphic column for the onshore part of the Sydney Mines Formation, subdivided into 14 cylothems (after Gibling et al. 2004). The fossil site occurs within the early Cantabrian Point Aconi cyclothem (No. 14).

Fig. 3. (below) The sedimentary succession at Point Aconi (after Falcon-Lang 2006) showing in detail the 3.1-m-thick plant-bearing beds (A-F) above the Point Aconi Coal. The Macroneuropteris tree, which forms the focus of this paper, is rooted on top of Plant Bed D and buried by grey mudstone of Plant Beds E and F. Grain size given on the $\mathrm{x}$-axis of the graphic logs is as follows: from left to right, $\mathrm{C}$, claystone, $\mathrm{S}$, siltstone, $\mathrm{F}$, fine-grained sandstone, $\mathrm{M}$, medium-grained sandstone, $\mathrm{C}$, coarse-grained sandstone.

\section{KEY TO LOGS}

\section{Lithology

\begin{tabular}{ll} 
& Coal \\
\hline & Grey mudstone \\
\hline & Red mudstone \\
\hline Sandstone \\
Siderite nodules \\
Calcrete nodules
\end{tabular}

\section{Sedimentary structures}

:* Oxidation mottles

त Ripple cross-lamination

$凶$ Trough cross-bedding

$\equiv$ Horizontal lamination

$\approx$ Symmetrical ripple marks

Pseudo-anticlines

- Inclined Stratification

\section{Faunal remains}

㳕 Diplichnites trackway

Agglutinated forams

\section{Autochthonous plants}

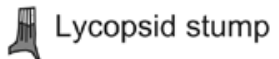

Stigmarian roots

if Indeterminate rootlets

Tree-fern $\$$ Medullosan

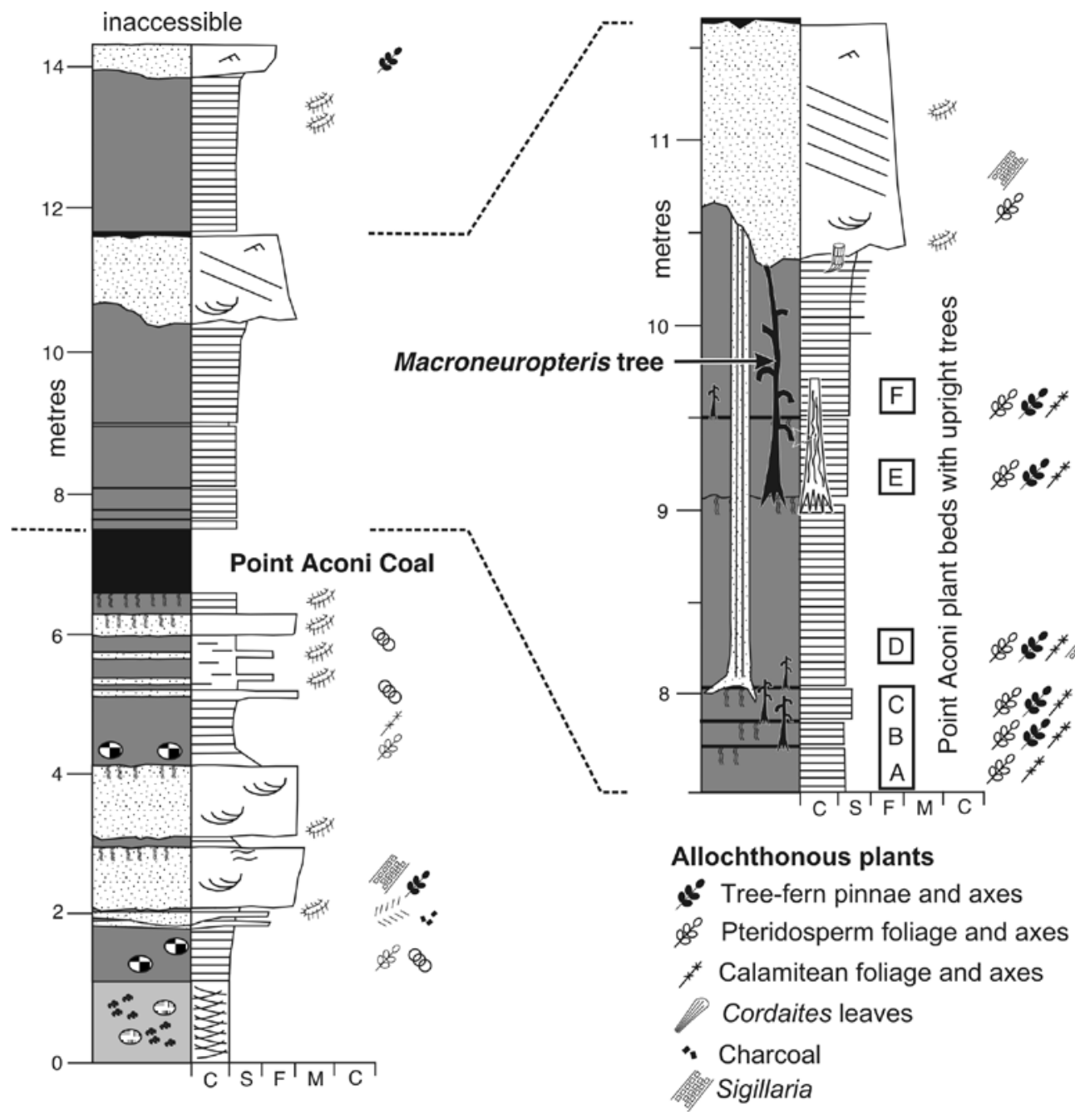


that these were anything other than freshwater wetlands, although brackish water influence cannot be entirely ruled out (Gibling and Wightman 1994).

\section{FOSSIL ASSEMBLAGES}

Plant fossils are highly abundant in the 3.1-m-thick succession above the Point Aconi Coal and six plant beds are recognized (Fig. 3). The lower three beds (A-C) are dark-grey shale with thin coaly shale, totalling $0.53 \mathrm{~m}$ in thickness. They exhibit $100 \%$ surface cover by plant adpressions. More than $95 \%$ of this plant material comprises remains of medullosan pteridosperms, including trunks $\leq 95 \mathrm{~mm}$ in diameter that show resin rodlets and downward-recurved petioles, large bifurcating petioles $\leq 56 \mathrm{~mm}$ in diameter, and pinnae of Macroneuropteris scheuchzeri with cyclopterid pinnules, and Neuropteris ovata. Non-medullosans are rare and comprise Calamites sp., Annularia sp., Asterophyllites equisetiformis, Paleostachya sp., Sphenophyllum oblongifolium, and Pecopteris sp.

Plant bed D is a $0.74 \mathrm{~m}$ thick, medium-grey laminated mudstone that shows $40-50 \%$ surface cover by plant adpressions in its lower part. This unit comprises the world-famous Point Aconi Plant Bed, which has been given provisional conservation status through the global GEOSITES initiative (Cleal and Thomas 1997; Wimbledon et al. 1999). It is beyond the scope of this paper to give a full inventory of morphospecies for this exceptionally diverse and well-preserved assemblage, but remains are dominated by medullosan pteridosperms and include pinnae of Macroneuropteris scheuchzeri with cyclopterid pinnules, Neuropteris ovata, and trunks with downwardrecurved petioles. The only other common morphospecies is Asterophyllites equisetiformis. Of the many other plants that occur rarely, representatives of the lycopsids, sphenopsids, ferns, pteridosperms, and cordaitaleans are present.

Plant beds E and F are $0.44 \mathrm{~m}$ and $1.12 \mathrm{~m}$ thick respectively, and contain abundant plant fossils, especially near their base, where $40-50 \%$ of the bedding surfaces are covered by adpressions. As with all the other plant beds in this succession, medullosan pteridosperm remains are dominant and comprise Macroneuropteris scheuchzeri with cyclopterid pinnules, Neuropteris ovata, and trunks with downward-recurved petioles. Other rare plants include Calamites sp., Asterophyllites equisetiformis, Paleostachya sp., Sphenophyllum oblongifolium, and Pecopteris sp.

\section{TREES IN GROWTH POSITION}

Fossil trees are rooted on top of plant beds A, B, C, D, and E, and in the upper part of $\mathrm{F}$, indicating a sporadically vegetated wetland landscape (Fig. 3). A few of these trees comprise lycopsids, calamiteans, and tree ferns, all types previously documented at many other sites (Gastaldo 1992; Calder et al. 1996, 2006; DiMichele et al. 1996; Falcon-Lang 2006). However, the most common variety of upright tree in these beds is a type never before described in the literature. Their architecture and association with plant beds dominated by Macroneuropteris scheuchzeri strongly imply that they are upright tree trunks of this species. The largest and most completely preserved of these trees (described in detail below and in Figure 4) is rooted in the paleosol (inceptisol) that overlies Plant Bed D and buried to a height of $1.31 \mathrm{~m}$ in Plant Beds $\mathrm{E}$ and $\mathrm{F}$. This tree was observed annually over a four-year period (2004-2007) as it slowly eroded out of the sea-cliffs.

The tree comprises a stout monoaxial trunk bearing numerous petioles (Fig. 4). The trunk sharply tapers from $446 \mathrm{~mm}$ diameter at the base to $91 \mathrm{~mm}$ diameter, $1 \mathrm{~m}$ above the paleosol in which it is rooted, and is tilted at $\sim 76^{\circ}$. Where locally pyritized, trunk wood shows resin rodlets. Abundant, closely spaced and downward-recurved petioles are helically borne on the lower part of the trunk. These petioles have a basal diameter of 33-49 $\mathrm{mm}$, show a single dichotomy, and have a preserved length of $0.6-1.9 \mathrm{~m}$. They are interpreted as senescent petioles that formed a prominent skirt around the base of the tree and may have played a role propping up the trunk. Pinnae of Macroneuropteris scheuchzeri occur in the mudstone adjacent to these drooping petioles. However, although orientated in the same plane, attachment of foliage to a petiole could not be demonstrated. The uppermost preserved part of the trunk is $74 \mathrm{~mm}$ diameter and bears petioles that are in an upright or horizontal orientation. These erect but incompletely preserved structures are interpreted as petioles that were alive at the time of burial and bore large leaf fronds. Beneath the tree trunk, the paleosol comprises a rooted mound, $\leq 0.35 \mathrm{~m}$ high, while around the lower part of the tree, mudstone entombs the downward-recurved petioles forming a sedimentary mound. This latter feature is interpreted as a sedimentary accumulation formed by the baffling effects of the skirt.

The occurrence of downward-recurved petioles and resin rodlets in the wood strongly suggests that this tree was a medullosan pteridosperm (Zodrow 2002, 2003; Laveine and Behlis, 2007). Furthermore the intimate facies association of this tree with foliage of Macroneuropteris scheuchzeri in the same plane as the petioles suggest an identity with this morphospecies. This is further supported by the fact that Macroneuropteris scheuchzeri is the dominant plant in this bed. Similar, but much smaller trees with preserved heights of $\leq 27 \mathrm{~cm}$ and downwardrecurved branches also occur on top of plant bed A, B, C, and E. Associated with dense accumulations of Macroneuropteris scheuchzeri, these latter trees are interpreted as juvenile specimens of this same plant. Sedimentary mounds developed around the skirt of these trees clearly show that they grew in a rapidly aggrading setting and acted to locally trap sediment.

\section{ACKNOWLEDGEMENTS}

HFL acknowledges a Natural Environment Research Council Fellowship (2002-2005), a Leverhulme Early Career Fellowship (2007-2008) and a Natural Environment Research Council Advanced Fellowship (2009-present) during the 

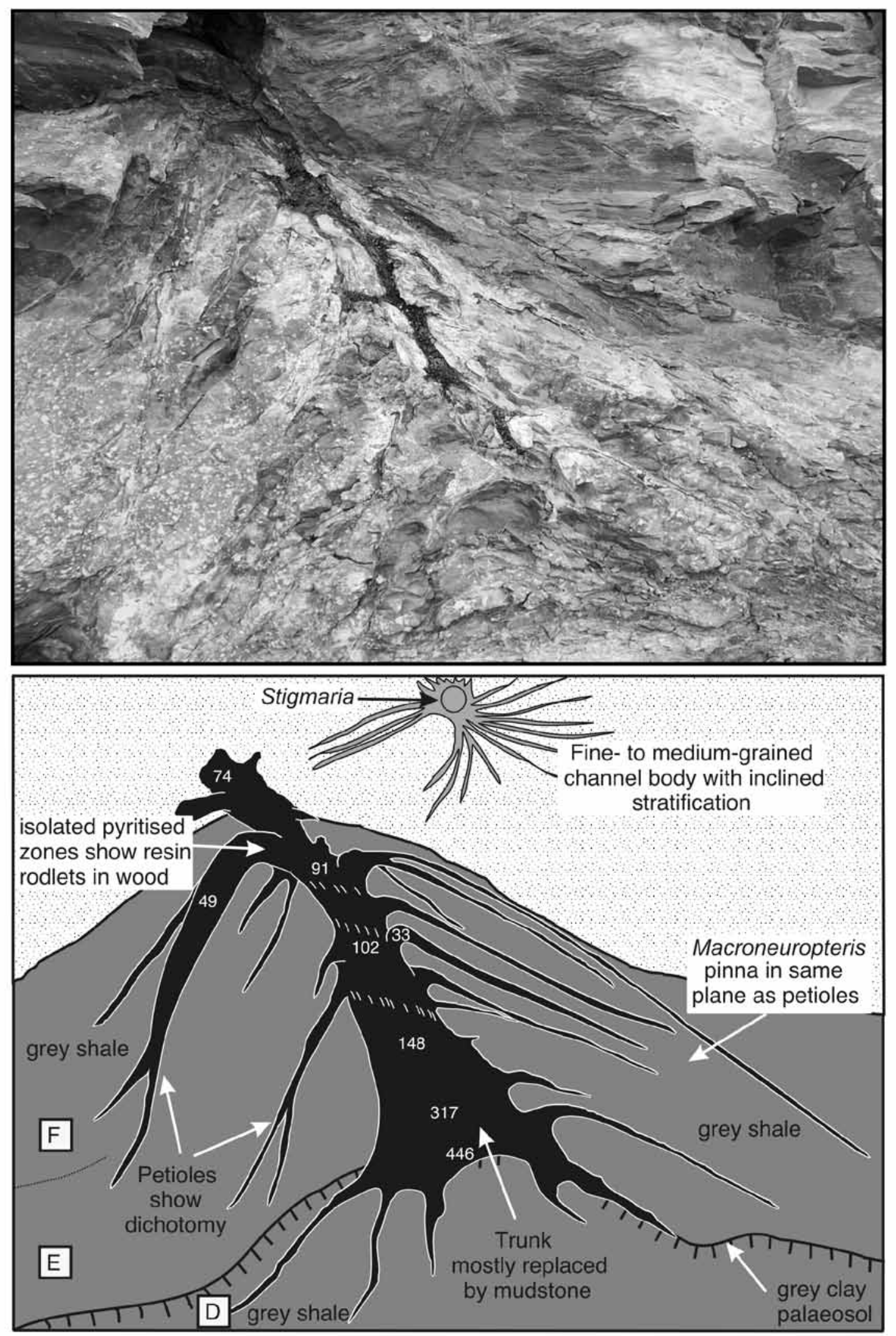

Fig. 4. The Macroneuropteris tree above the Point Aconi Coal Seam. (A) Photograph of tree as observed in August 2005 and (B) Interpreted sketch of tree based on continuous observation from 2004-2007. Numbers indicate diameter of trunk and petiole in millimetres. 
course of this work. Fieldwork in 2006 was generously funded through the J.B. Tyrell Fund of the Geological Society. I thank Mitch Blake, an anonymous reviewer, and the editor, Rob Fensome, whose comments improved this paper.

\section{REFERENCES}

Beeler, H.E. 1983. Anatomy and frond architecture of Neuropteris ovata and N. scheuchzeri from the Upper Pennsylvanian of the Appalachian Basin. Canadian Journal of Botany 61, pp. 2352-2368. doi:10.1139/b83-259

Calder, J.H., Gibling, M.R., Eble, C.F., Scott, A.C., and MacNeil, D.J. 1996. The Westphalian D fossil forest at Table Head, Sydney Basin, Nova Scotia: sedimentology, paleoecology and floral response to changing edaphic conditions. International Journal of Coal Geology 31, pp. 277-313. doi:10.1016/S0166-5162(96)00020-1

Calder, J.H., Gibling, M.R., Scott, A.C., Davies, S.J., and Hebert, B.L. 2006. A fossil lycopsid forest succession in the classic Joggins section of Nova Scotia: paleoecology of a disturbance-prone Pennsylvanian wetland. In Wetlands through Time. Edited by S. Greb and W.A. DiMichele, Geological Society of America, Special Paper 399, pp. 169-196.

Cleal, C.J., and Thomas, B.A. 1997. A provisional list of GEOSITES for Carboniferous palaeobotany. Newsletter on Carboniferous Stratigraphy 15, pp. 32-33.

Cleal, C.J., Shute, C.H. and Zodrow, E.L. 1990. A revised taxonomy for Palaeozoic neuropterid foliage. Taxon 39, pp. 486-492. doi:10.2307/1223109

Cleal C.J., Laveine J.P., and Shute, C.H. 1996. Architecture of the Upper Carboniferous pteridosperm frond Macroneuropteris macrophylla. Palaeontology 39, pp. 561-582.

Cleal, C.J., Laveine J.P., and Shute, C.H. 1998. Further observations on the Upper Carboniferous pteridosperm frond $\mathrm{Mac}$ roneuropteris macrophylla. Palaeontology 41, pp. 383-386.

Cleal, C.J., Dimitrova, T.K., and Zodrow, E.L. 2003. Macrofloral and palynological criteria for recognising the Westphalian-Stephanian boundary. Newsletter on Stratigraphy 39, pp. 181-208.

DiMichele, W.A., Eble, C.F., and Chaney, D.S. 1996. A drowned lycopsid forest above the Mahoning coal (Conemaugh Group, Upper Pennsylvanian) in eastern Ohio, USA. International Journal of Coal Geology 31, pp. 249-276. doi:10.1016/S0166-5162(96)00019-5

DiMichele, W.A., Phillips, T.L., and Pfefferkorn, H.W. 2006. Paleoecology of Late Paleozoic pteridosperms from tropical Euramerica. Journal of the Torrey Botanical Society 133, pp. 83-118. doi:10.3159/1095-5674(2006)133[83:POLPPF] 2.0.CO;2

Dolby, G. 1988. The palynology of the Morien Group, Sydney Basin, Cape Breton Island, Nova Scotia. Nova Scotia Department of Natural Resources, Open-File Report 88-061,. 21 p.

Falcon-Lang, H.J. 2006. Latest Mid-Pennsylvanian tree-fern forests in coastal plain deposits, Sydney Mines Formation,
Nova Scotia, Canada. Journal of the Geological Society, London 163, pp. 81-94. doi:10.1144/0016-764905-003

Falcon-Lang, H.J. 2008. Marie Stopes, the discovery of pteridosperms, and the origin of Carboniferous coal balls. Earth Sciences History 27, pp. 81-102.

Gastaldo, R.A. 1992. Regenerative growth in fossil horse-tails following burial by alluvium. Historical Biology 6, pp. 203219. doi:10.1080/10292389209380429

Gibling, M.R., and Wightman, W.G. 1994. Palaeovalleys and protozoan assemblages in a Late Carboniferous cyclothem, Sydney Basin, Nova Scotia. Sedimentology 41, pp. 699-719. doi:10.1111/j.1365-3091.1994.tb01418.x

Gibling, M.R., Saunders, K.I., Tibert, N.E., and White, J.A. 2004. Sequence sets, high-accommodation events and the coal window in the Carboniferous Sydney Coalfield, Atlantic Canada. In Coal-bearing strata: sequence stratigraphy, paleoclimate, and tectonics. Edited by J. Pashin and R.A. Gastaldo. American Association of Petroleum Geologists Studies in Geology Series, 51, pp. 169-198.

Keferstein, C. 1826. Teutschland Geognostisch-Geologisch Dargestellt, mit Charton und welche einen geognostische Atlas Bilden, I. Stück Weimar, pp. 158-159.

Laveine, J-P., and Belhis, A. 2007. Frond architecture of the seed-fern Macroneuropteris scheuchzeri, based on Pennsylvanian specimens from the Northern France Coal Field. Palaeontontographica, Abt B. 277, pp. 1-41.

Lhwyd, E. 1699. Lithophylacii britannici ichnographia. First Edition. Printed for the subscribers, London, 139 pp., 23 pls.

Pfefferkorn, H.W., Gillespie, W.H., Resnick, D.A., Scheihing, M.H. 1984. Reconstruction and architecture of medullosan pteridosperms (Pennsylvanian). The Mosasaur 2, 1-8.

Schabilion, J.T., and Reihman, M.A. 1985. Petrified Neuropteris scheuchzeri pinnules from the Middle Pennsylvanian of Iowa: a paleoecological interpretation. Compte Rendu Congrès International de Stratigraphie et de Géologie du Carbonifère 5, pp. 3-12.

Scheuchzer, J.J. 1709. Herbarium diluvianum, Tiguri, Zurich, $44 \mathrm{pp}$.

Scheuchzer, J.J. 1723. Herbarium diluvianum. Editio novissima dulpo auctior. Petri Vander, Lugduni Batavorum, Utrecht, 119 pp.

Stewart, W.N., and Delevoryas, T. 1956. The medullosan pteridosperms. Botanical Review, 22, pp. 45-80. doi:10.1007/ BF02872456

Wagner, R.H., and Lyons, P.C. 1997. A critical analysis of the higher Pennsylvanian megafloras of the Appalachian region. Review of Palaeobotany and Palynology 95, pp. 255283. doi:10.1016/S0034-6667(96)00037-1

Wimbledon, W.A.P., Andersen, S., Cleal, C.J., Cowie, J.W., Erikstad, L., Gonggrijp., G.P., Johansson, C.E., Karis, L.O., and Suominen, V. 1999. Geological World Heritage: GEOSITES - a global comparative site inventory to enable priorisation for conservation. Proceedings of the Second International Symposium on the Conservation of the Geo- 
logical Heritage. Memoirs of the Geological Survey of Italy, pp. 45-60.

Wnuk, C., and Pfefferkorn, H.W. 1984. The life habits and paleoecology of Middle Pennsylvanian medullosan pteridosperms based on an in situ assemblage from the Bernice Basin (Sullivan County, Pennsylvania, U.S.A.). Review of Palaeobotany and Palynology 41, pp. 329-351. doi:10.1016/0034-6667(84)90053-8

Zodrow, E.L. 1989a. Summary of macrofloral biostratigraphy of the Sydney Coalfield, Nova Scotia, Canada (Carboniferous, Westphalian/Cantabrian age). Atlantic Geology 25, pp. 73-79.

Zodrow, E.L. 1989b. Revision of sphenophyll biostratigraphy of Canada. Review of Palaeobotany and Palynology 58, pp. 301-331. doi:10.1016/0034-6667(89)90090-0
Zodrow, E.L. 2002. The "medullosan forest" at the Lloyd Cove Seam (Pennsylvanian, Sydney Coalfield, Nova Scotia, Canada). Atlantic Geology 38, pp. 177-195.

Zodrow, E.L. 2003. Foliar forms of Macroneuropteris scheuchzeri (Pennsylvanian, Sydney Coalfield, Nova Scotia, Canada). Atlantic Geology 39, pp. 23-37.

Zodrow, E.L., and Cleal, C.J. 1985. Phyto- and chronostratigraphical correlations between the late Pennsylvanian Morien Group (Sydney, Nova Scotia) and the Silesian Pennant Measures (South Wales). Canadian Journal of Earth Sciences 22, pp. 1465-1473. doi:10.1139/e85-152

Editorial responsibility: Robert A. Fensome 